\title{
DDC Gene
}

National Cancer Institute

\section{Source}

National Cancer Institute. DDC Gene. NCI Thesaurus. Code C128874.

This gene plays a role in the synthesis of monoamine neurotransmitters. 